\title{
Teaching Video NeuroImages: A Case of Lance Adams Syndrome With Seesaw Nystagmus
}

Gabriela Keeton, MD, Tarek Ali, MBBS, Padmaja Sudhakar, MD, and Zain Guduru, MD

Neurology ${ }^{\circledR} 2021 ; 96:$ e816. doi:10.1212/WNL.0000000000010741

Seesaw nystagmus ( $\mathrm{SSN}$ ) is a rare ocular manifestation characterized by cyclic movement of the eyes with a conjugate torsional component and a disjunctive vertical component. We present a 29-year-old woman with alcohol withdrawal seizure resulting in anoxic brain injury secondary to respiratory failure. On examination, she had multifocal myoclonus, dystonia, and SSN (video). The proposed mechanism is inactivation of the torsional eye-velocity integrator, the interstitial nucleus of Cajal, with sparing of the torsional fast-phase generator, the rostral interstitial nucleus of MLF. This is a unique case of Lance Adams syndrome ${ }^{1,2}$ combined with SSN.

\section{Study Funding}

No targeted funding reported.

\section{Disclosure}

The authors report no disclosures relevant to the study. Go to Neurology.org/N for full disclosures.

\section{Appendix Authors}

\begin{tabular}{lll}
\hline Name & Location & Contribution \\
\hline $\begin{array}{l}\text { Gabriela Keeton, } \\
\text { MD }\end{array}$ & $\begin{array}{l}\text { University of } \\
\text { Kentucky }\end{array}$ & $\begin{array}{l}\text { Drafting and revision of case writeup, organized different components } \\
\text { for submission }\end{array}$ \\
\hline Tarek Ali, MBBS & $\begin{array}{l}\text { University of } \\
\text { Kentucky }\end{array}$ & Revision for intellectual content \\
\hline $\begin{array}{l}\text { Padmaja } \\
\text { Sudhakar, MD }\end{array}$ & $\begin{array}{l}\text { University of } \\
\text { Kentucky }\end{array}$ & Revision for intellectual content \\
\hline Zain Guduru, MD & $\begin{array}{l}\text { University of } \\
\text { Kentucky }\end{array}$ & Drafting and revision of case writeup, video editing and formatting \\
\hline
\end{tabular}

\section{References}

1. Lance JW, Adams RD. The syndrome of intention or action myoclonus as a sequel to hypoxic encephalopathy. Brain 1963;86:111-136.

2. Werhahn KJ, Brown P, Thompson PD, Marsden CD. The clinical features and prognosis of chronic posthypoxic myoclonus. Mov Disord 1997;12:216-220.

\author{
Correspondence \\ Dr. Keeton \\ grke226@uky.edu
}

MORE ONLINE

๑ Video

$\rightarrow$ Teaching slides

links.lww.com/WNL/

B202 


\section{Neurology}

\section{Teaching Video NeuroImages: A Case of Lance Adams Syndrome With Seesaw Nystagmus}

Gabriela Keeton, Tarek Ali, Padmaja Sudhakar, et al. Neurology 2021;96;e816 Published Online before print September 11, 2020

DOI 10.1212/WNL.0000000000010741

This information is current as of September 11, 2020

\section{Updated Information \&} Services

References

Subspecialty Collections

\section{Permissions \& Licensing}

Reprints including high resolution figures, can be found at: http://n.neurology.org/content/96/5/e816.full

This article cites 2 articles, 0 of which you can access for free at: http://n.neurology.org/content/96/5/e816.full\#ref-list-1

This article, along with others on similar topics, appears in the following collection(s):

Clinical neurology examination

http://n.neurology.org/cgi/collection/clinical_neurology_examination Dystonia

http://n.neurology.org/cgi/collection/dystonia

Motor Control

http://n.neurology.org/cgi/collection/motor_control

Myoclonus

http://n.neurology.org/cgi/collection/myoclonus

Nystagmus

http://n.neurology.org/cgi/collection/nystagmus

Information about reproducing this article in parts (figures,tables) or in its entirety can be found online at:

http://www.neurology.org/about/about_the_journal\#permissions

Information about ordering reprints can be found online:

http://n.neurology.org/subscribers/advertise

Neurology ${ }^{\circledR}$ is the official journal of the American Academy of Neurology. Published continuously since 1951, it is now a weekly with 48 issues per year. Copyright (C 2020 American Academy of Neurology. All rights reserved. Print ISSN: 0028-3878. Online ISSN: 1526-632X.

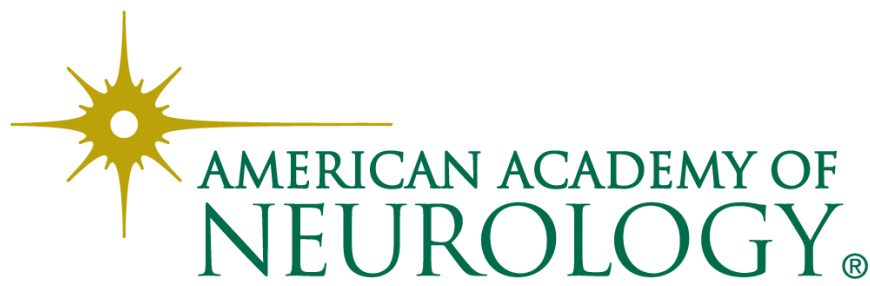

